\title{
PROSPECTS FOR THE IMPLEMENTATION OF NEW MATERIALS AND TECHNOLOGIES IN THE AEROSPACE INDUSTRY
}

\author{
Taras Yanko $^{1^{*}}$ (D) 0000-0003-2217-4290 \\ Olexii Dmytrenko ${ }^{2}$ (i) 0000-0001-6703-9979 \\ ${ }^{1}$ PJSC «Titanium Institute», 180 Sobornyi Av., Zaporizhzhya, 69035, Ukraine \\ ${ }^{2}$ National Science Center "Kharkiv Institute of Physics and Technology", Akademicha street 1, \\ Kharkiv, 61108, Ukraine \\ *titanlab3@ukr.net
}

\begin{abstract}
This article considers the main materials used to make aircraft, both fuselage and engines. First, the problems that force developers to introduce new materials in aircraft production are identified. We then present features of the introduction of heat-resistant titanium alloys, ways of improving the mechanical properties of parts made of titanium alloys, and methods of manufacturing complex details. Other promising materials for the aviation industry, such as high-entropy alloys, quasicrystals, carbon-carbon materials, and nickel foam, are also considered.

Keywords: engine, alloy, aerospace industry, powder, material, metal Type of the work: Research Article

\section{INTRODUCTION}

Overall, aerospace technologies currently make use of a wide range of different materials (see Fig. 1). However, given the increasing priority being placed on sustainable development and given the constant economic pressure for improved cost-efficiency, the aerospace industry is witnessing continuous ongoing improvement of hardware, materials and technologies. New materials, designs and manufacturing techniques are being developed, existing methods of obtaining products and structures are being improved, and new methods of enhancing the characteristics of existing materials are being developed $[1,2]$.
\end{abstract}




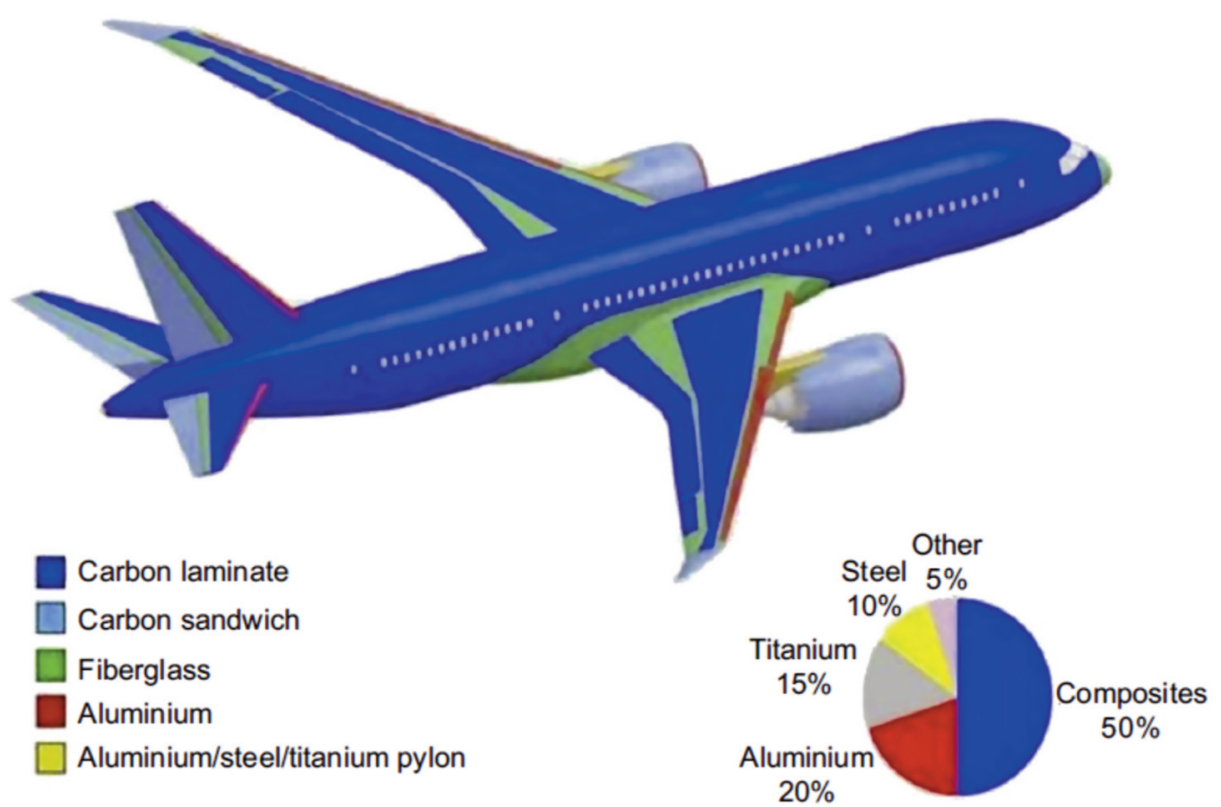

Fig. 1. Use of materials in the Boeing 747 (adapted from Brown, 2014).

The materials used in aerospace are currently mostly metal alloys, but they also include polymerbased and carbon materials that have either been developed for aerospace use or become well-known as a result of such applications. The aerospace industry often poses stringent requirements in terms of exceptional performance, strength or heat resistance, even at significant manufacturing or processing cost. Other materials are selected for their long-term reliability, especially for their resistance to fatigue, in this safety-focused field. However, the operational specifications for various components, assemblies and structures mean that the choice of materials with desired properties differ radically from detail to detail.

The need to reduce pollutant emissions and also to bolster economic gains prompts design engineers to develop aviation transport systems that provide optimal performance with a minimum level of energy consumption [3]. Aviation technologies require an optimal combination of both economic and environmental indicators, as well as safe and reliable engineering solutions. This outcome can be attained using high-performance materials with low density, in combination with design solutions $[4,5]$.

In this article we review the main materials used to make aircraft components, and consider the problems driving developers to introduce new materials. We then consider a range of new materials and technologies now on the horizon, including heat-resistant titanium alloys, techniques for bolstering the mechanical properties of titanium alloys, as well as such new materials as high-entropy alloys, quasicrystals, carbon-carbon materials, and nickel foam.

\section{TITANIUM ALLOYS}

In view of the above circumstances, titanium and its alloys are currently employed in fairly large volumes in the production of aerospace technology, but there are also a number of competing materials in use or in research (see Fig. 2). 


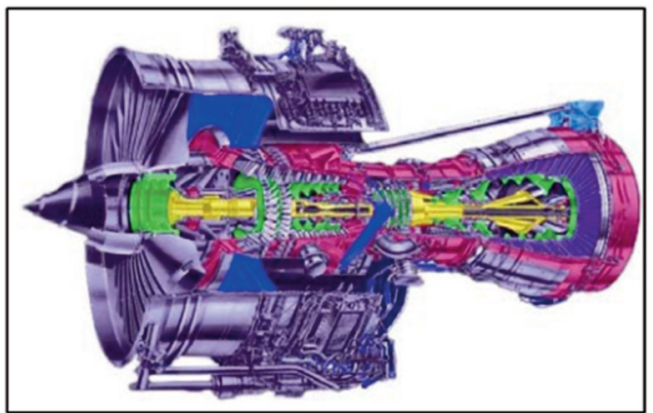

- CFRP fan blades for CFM LEAP

- Al-Li fan blades for P\&W GTF

- Large scale test of CFRP fan with CFRP containment case for Rolls Royce

- Current testing of CMC exhaust nozzle for Trent by Rolls Royce

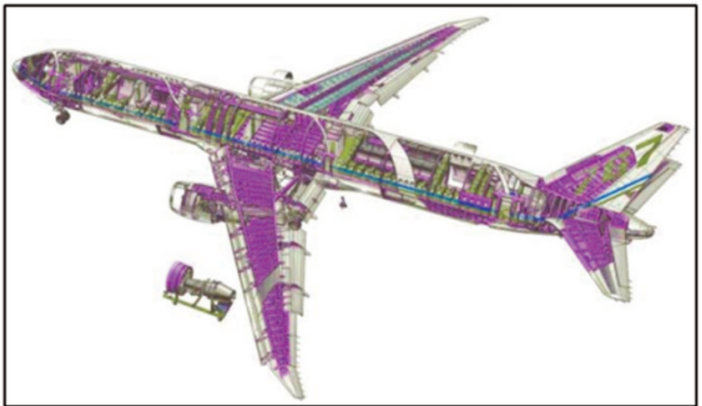

- Ongoing research on using $\mathrm{Al}-\mathrm{Li}$ to supplant $\mathrm{Ti}$ in various airframe parts

- Limited application of Ti+AL bonded hybrid for some structural applications

- Some examples of Ti 5553 being replaced with Ti 6-4 due to easy machining

Fig. 2. Materials competing with titanium - Engine vs Aerostructure [6].

Titanium is widely used in aerospace due to its unsurpassed properties: corrosion resistance, durability, ductility, and low density. However, modern requirements for the materials of aircraft body elements and engine parts limit the use of standard titanium alloys. Mainly, to solve the structural problems in "hot zones" or loaded areas, nickel superalloys are mostly used. As Fig. 3 illustrates, titanium alloys are used at temperatures below $730{ }^{\circ} \mathrm{C}$. However, the specific density of such nickel alloys is significantly higher than titanium alloys. Nickel alloys have a density of about $8 \mathrm{~g} / \mathrm{cm}^{3}$, in contrast to titanium alloys, with a density of $4-5 \mathrm{~g} / \mathrm{cm}^{3}$.

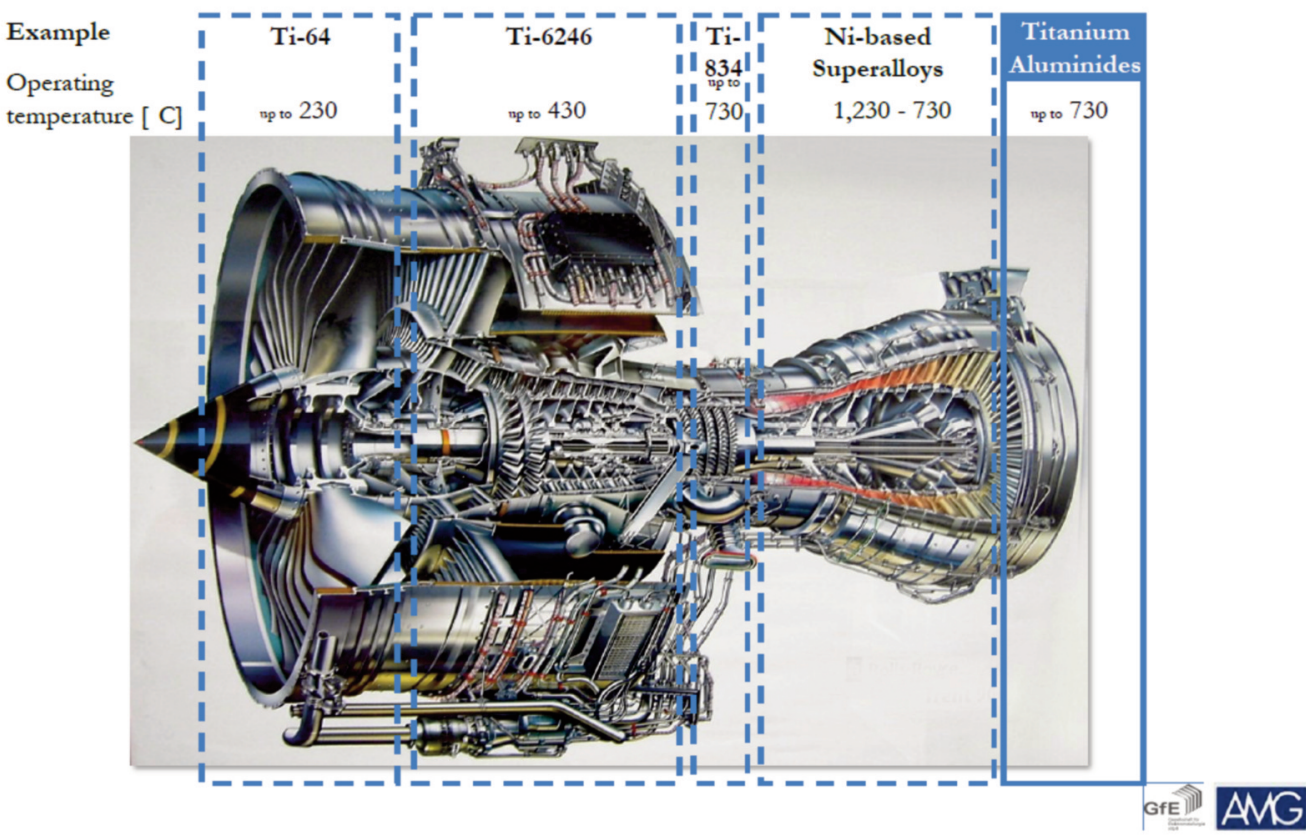

Fig. 3. Titanium alloys for Aircraft Engines [7]. 
Current commercial aircraft engines typically range in weight from 2 metric tons to more than 8 tons, with metal alloys comprising $85-95 \%$ of the weight of the engine [8]. The implementation of new lightweight alloys instead of nickel alloys is a current problem, because about half of the materials in an aircraft engine are nickel alloys (see Fig. 4).

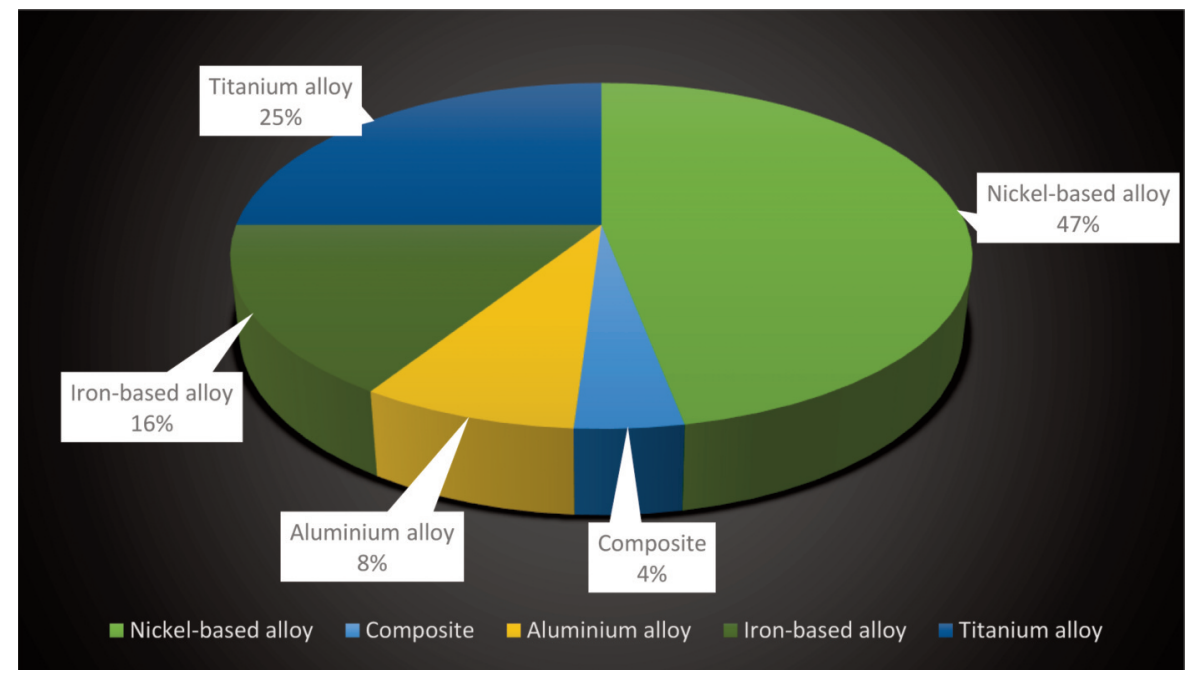

Fig. 4. Breakdown of materials used in a General Electric engine (CF6) for Boeing.

Using TNB alloy ( $\mathrm{Ti}-43.5 \mathrm{Al}-4 \mathrm{Nb}-1 \mathrm{Mo}-0.1 \mathrm{~B}$ at.-\%) instead of Ni-superalloys for high speed LPT blade applications in PW1100G ${ }^{\mathrm{TM}}$, engines are claimed to operate with very high Bypass Ratio of 12:1, use up to $12-15 \%$ less fuel, making engines $15-20 \mathrm{db}$ less noisy with lower emissions (2,700-3,600 tons less $\mathrm{CO}_{2}$ per year per aircraft, and 50-55\% less $\mathrm{NOx}$ ) [9, 10]. Replacing Ni-based superalloy parts with titanium aluminides will reduce the structural weight of components by $20-30 \%$. General Electric have tried to introduce such $\gamma$-TiAl alloys into LPT blade production, in particular for the GEnx aircraft engine (www.geaviation.com).

Currently, the following industrial alloys of the aluminide type have been developed: VTI-4 (Russia), Ti-22-23 (United States), Ti-22-20-3 (China), Ti-22-20-2 (Japan), Ti-22-20-2-0,5 (France). These alloys are based on $\mathrm{Ti}(20-23)-\mathrm{Al}(20-25)-\mathrm{Nb}(1-5)$ (at. $\%$ ) composition. Other elements include: $\mathrm{V}+\mathrm{Mo}+\mathrm{Zr}+\mathrm{Si}$ (Russia), Ta (China), W (Japan), Mo+Si (France), B (United States) and others [11]. Further developments in the improvement of such alloys include the use of more complex systems of gamma-alloys, high-entropy systems, and dispersed reinforced materials or composite materials.

\section{HIGH ENTROPY ALLOYS}

Another type of material with remarkable hardness, yield stress, high-temperature oxidation resistance and fracture strength can be found in high entropy alloys (HEAs). Such alloys have a good work hardenability and plastic strain. Moreover, HEAs exhibit technologically attractive magnetic properties together with good erosive and wear resistance. In view of such properties, HEAs can be used as a refractory, fatigue-resistant material. In the form of films and coatings resistant to corrosion surface layers, such materials can prevent destructive diffusion for various structural elements of jet engines [12].

The widespread introduction of such materials is limited by the complexity of production and machining [13, 14]. Modern additive technologies allow near net shape details to be obtained. The widespread use of $3 \mathrm{D}$ printing for alloys of this type, at the present stage of development in industrial 
batch production, remains restrained in practice by the high cost of equipment and raw materials for production in comparison with traditional technologies. The introduction of technologies of precision microsphere casting [15] and continuous wire casting [16] may help to resolve these issues. HEA powder is produced through dynamic high-speed casting of microspheres using a multipoint plasma system. It is possible to use industrial or originally produced wires as raw materials. Using this complex installation of powder and wire production for printing, in combination with a $3 \mathrm{D}$-printer for the manufacture of metal alloys, offers the most effective and economically viable way of product manufacturing by 3D-printing.

Another way to boost the heat resistance of aircraft engine parts involves applying heat-resistant coatings [17, 18, 19]. Enhanced engine efficiency, ecology and reliability can be achieved with the application of protective coatings, through a notable reduction of their manufacturing weight. This new trend in coating system development includes depositing multilayer, gradient and modified coatings.

\section{QUASICRYSTALS}

Another promising type of material for thermal barrier coatings is quasicrystals (QC): inter-metallic phases where the structure of metal is represented by the geometrical figure known as the icosahedron (Fig. 5). Normally, metal unit cells are based on cube, tetra- and/or octahedron shapes.
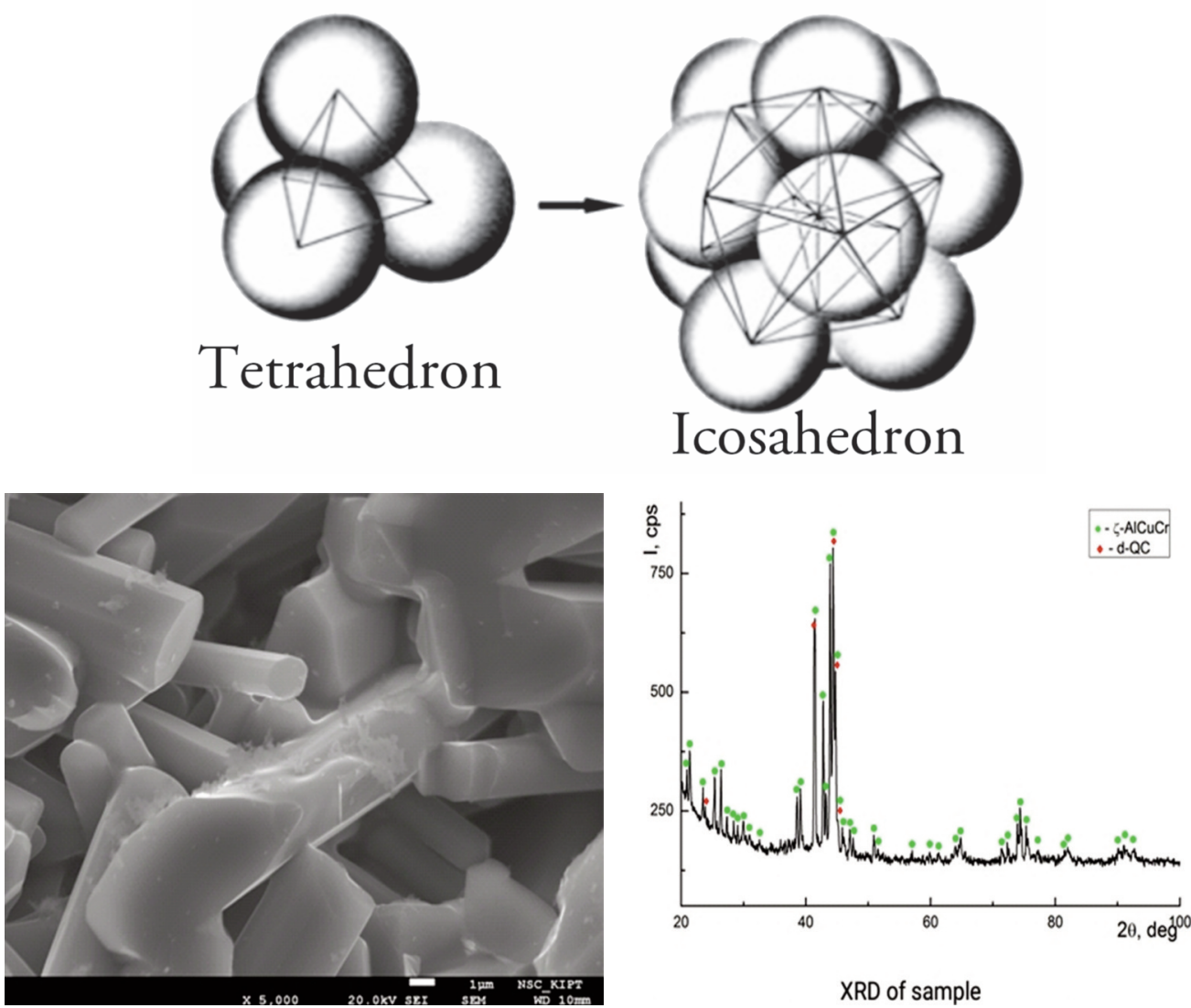

Fig. 5. Unit cells of quasi crystals and SEM of d-QC $\mathrm{Al}_{73} \mathrm{Cu}_{11} \mathrm{Cr}_{16}$ stable decagonal QC. 
Quasi crystals could be considered an intermediate state between crystals and amorphous materials. Synthesis of such phases requires higher cooling and crystallization rates as compared to those for conventional processes.

Some QCs have extremely low thermal conductivity, which makes it possible to use coatings made of them as thermal barriers in elements of various engines [20]. It is notable that QCs possess thermal expansion coefficient values close to that of structural metal, bringing increased resistance to thermal cycling.

Bench tests of engines with $\mathrm{QC} \mathrm{Al}-\mathrm{Co}-\mathrm{Fe}-\mathrm{Cr}$ as thermal barriers have been successfully carried out and also patented [19, 21, 22, 23]. In the United States, QCs are expected to be used for coatings on rocket bodies due to their high hardness and wear resistance at elevated temperatures [24].

The urgent need to reduce global emissions raises the question of developing more environmentally friendly technologies. Some modern aviation projects are considering ways of using hydrogen as a fuel, in liquid or gaseous form $[25,26]$. Therefore, there is a need to develop technologies and materials that either allow significant amounts of hydrogen to be accumulated, or create conditions for rapid, safe and efficient production of hydrogen while air travel is underway. The use of QCs or compounds based on the Laves phase $\mathrm{C} 14 \mathrm{~L}-\mathrm{Ti}-\mathrm{Zr}-\mathrm{Ni}$, capable of reversible absorption of significant amount of hydrogen, offer promising avenues of research for hydrogen energy [27].

\section{NICKEL FOAM}

Another material that can significantly improve the hydrogen production conditions for green aviation is porous nickel foam. High-quality $\mathrm{Ni}$ foam is used as the electrode material in HEV batteries. Nickel's chemical purity, large specific surface area and uniform layer thickness make it possible to obtain nickel foam with a specific weight of $0.15 \mathrm{~g} / \mathrm{cm}^{3}$. Nickel foam obtained by the carbonyl scheme offers an impressive combination of low density with high ductility and low thermal conductivity [28].

One of the effective ways of improving the characteristics of the gas turbine engine lies in reducing the radial gaps between the tips of the rotor blades and the working rings of the stator, as well as the gaps in the labyrinth seals. Studies have shown that $5 \%$ of engine efficiency is lost due to leaks in radial clearances [29]. To eliminate these defects, run-in coatings and materials are used.

The key requirements for such materials include:

- a low coefficient of friction and low hardness;

- being easily run-in; if necessary, the seal material should allow the blade ends to easily cut into, while at the same time not wearing out the blade material;

- having sufficient erosion resistance, working effectively throughout the entire resource of the unit;

- having sufficient anti-seize properties;

- when plunging, the seal material must not crack, crumble;

- particles that have separated from the seal material as a result of cutting should be carried away by the gas flow along the gas path and not stick to engine parts; particles should in particular not stick to parts and blades that have perforations for air cooling;

- titanium blades, when touching and cutting into the seal material, should not give rise to sparks that could cause an engine fire;

- the seal material must have sufficient heat resistance.

Given these requirements, porous nickel foam is the optimal material for use in this area (Fig. 6). 

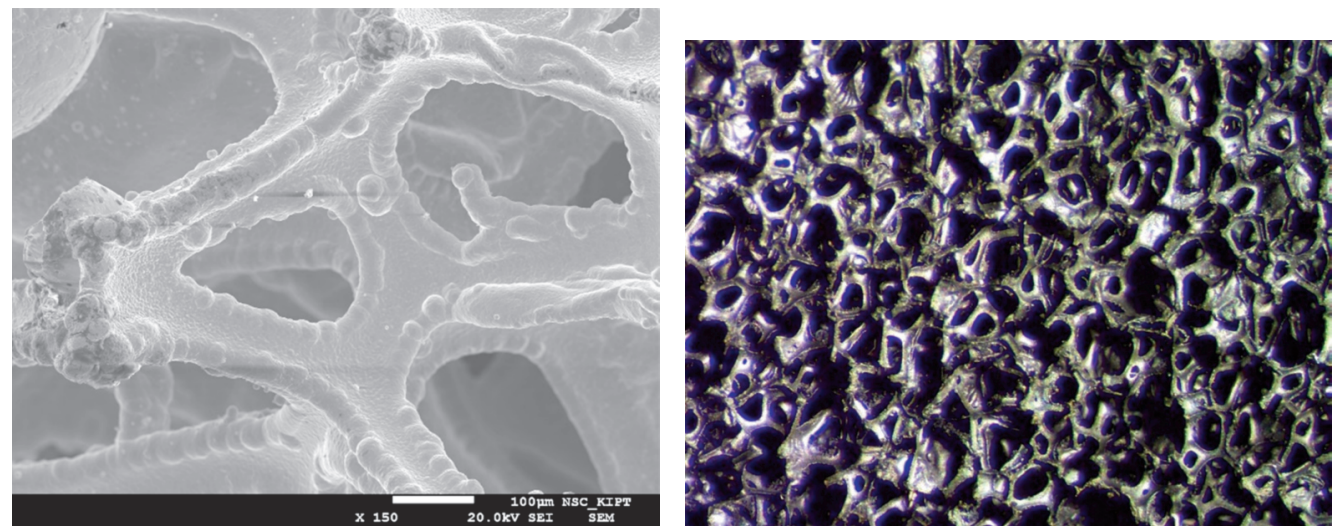

Fig. 6. Nickel foam after heat treatment.

Applications of $\mathrm{Ni}$ foam as sound-absorbing structures and structural elements of ultra-light aircraft are under development [30].

\section{CARBON-CARBON COMPOSITES}

Carbon-carbon (C-C) composites are a group of advanced materials made of carbon. They consist of carbon matrix based on carbon fibres, embedded precursors and carbon nanotubes (CNTs). Carboncarbon matrix composites have an advanced combination of mechanical properties, which makes them highly interesting engineering materials for aerospace industries. The main applications of $\mathrm{C}-\mathrm{C}$ composites in the aerospace industry lie in high friction systems for braking devices. There are also examples of $\mathrm{C}-\mathrm{C}$ composite applications in heat extreme conditions in heat-shields or nozzles in rocket motors, because of the high load-bearing ability of C-C composites at high temperatures [31, 32, 33, 34]. There are successful cases of carbon composite fan blades, which will debut in the GE9X [35]. They are part of the fourth generation of such blades and will also have improved aerodynamics. Existing GE engines that incorporate carbon composite fan blades are the GE90-94B, GE90-115B, and GEnx engines.

\section{CONCLUSIONS}

The main factor driving the development of new materials and technologies in the aerospace sector is the need to reduce aircraft weight, thereby lowering harmful emissions. Another direction of technological progress towards resolving the problem of emissions involves the development of hydrogen technologies and materials. Further development of advanced technologies lies in the creation of new materials with both complex chemical composition and composite structure. This promising approach will create ultra-light, corrosion-resistant, heat-resistant materials with exceptional mechanical properties. In this article we have reviewed a number of promising materials and technologies in this respect: new alloys based on refractory metals such as titanium and zirconium, high-entropy alloys, quasicrystals, as well as carbon-carbon materials and nickel foam. 


\section{REFERENCES}

[1] Kandasamy Jayakrishna, Vishesh R. Kar, Mohamed T.H. Sultan \& Murugan Rajesh, 2018, 1 - Materials selection for aerospace components, Ed.: Mohammad Jawaid, Mohamed Thariq, In Woodhead Publishing Series in Composites Science and Engineering, Sustainable Composites for Aerospace Applications, Woodhead Publishing, Pages 1-18, DOI: 10.1016/B978-0-08-1021316.00001-3.

[2] Huda, Z. \& Edi, P., 2013, "Materials selection in design of structures and engines of supersonic aircrafts: A review”. Materials \& Design, 46, pp. 552-560. DOI: 10.1016/j.matdes.2012.10.001.

[3] Mitsuhiro, T. \& Masashi, K., 2014, "Making lighter aircraft engines with titanium aluminide blades". IHI Engineering Review, 47(1), pp. 10-13.

[4] Mouritz, A.P., 2012, Introduction to aerospace materials, 1st ed., Woodhead Publishing, Suite, Philadelphia, USA.

[5] Alderliesten R., 2018, Introduction to Aerospace Structures and Materials. Netherlands; pp. 41-58. DOI: $10.5074 / \mathrm{t} .2018 .003$.

[6] Rolls-Royce. http://www.rolls-royce.com/about/technology/gas turbine tech/.

Accessed on 19-12-2012.

[7] AMG. http://www.amg-nv.com/Innovation/Titanium-Aluminide/default.aspx.

Accessed on 18-01-2013.

[8] Schafrik, R. \& Sprague, R., 2004, "Siga of gas turbine materials: Part I; Modern aeropropulsion is possible only because of the engine materials that have enabled continuous improvement in hightemperature operation, higher power, and reduced weight over the past 50 years. This is the first of a four-part series about development of gas turbine engine materials". Advanced Materials \& Processes, 162(3), pp. 33-36.

[9] 'P1100G - MTU AeroEngines', available at http://www.mtu.de/engines/civil-aircraftengines/narrowbody-and-regional-jets/pw1000g/, Accessed on 18-11-2015.

[10] Clemens, H., Smarsly, W., Gütherand, V. and Mayer, S., 2015, "Advanced intermetallic titanium aluminides", Proceedings of the 13th World Titanium Conference, San Diego, USA.

[11] Clemens, H. \& Mayer, S., 2016, "Intermetallic titanium aluminides in aerospace applications processing, microstructure and properties". Materials at High Temperatures, 33(4-5), pp. 560570, DOI: 10.1080/09603409.2016.1163792.

[12] Dada, M., Popoola, P., Adeosun, S., \& Mathe, N. R., 2019, "High entropy alloys for aerospace applications". IntechOpen. DOI: 10.5772/intechopen.84982.

[13] Castellanos, S. D., et al., 2019, "Machinability of titanium aluminides: A review". Proceedings of the Institution of Mechanical Engineers, Part L: Journal of Materials: Design and Applications, 233(3), pp. 426-451. DOI: 10.1177/1464420718809386.

[14] Hood, R., 2010, “The machinability of a gamma titanium aluminide intermetallic”. Doctoral dissertation, University of Birmingham.

[15] Yanko T.B. \& Datsenko R.B., 2018, "Method of dynamic high-speed casting of metal microspheres", Pat. UA 129499.

[16] Yanko T.B. \& Datsenko R.B., 2019, "Device for continuous casting of metal wires of small diameters from the active metals". Pat. UA 134397.

[17] 2009, "High-temperature resistant aero engine coatings", Aircraft Engineering and Aerospace Technology, 81(6). DOI: 10.1108/aeat.2009.12781 fad.001.

[18] Hetmańczyk, M., Swadźba, L. and Mendala, B., 2007, "Advanced materials and protective coatings in aero-engines application". Journal of Achievements in Materials and Manufacturing Engineering, 24(1), pp. 372-381. 
[19] Alqallaf, J., Ali, N., Teixeira, \& Addali, A., 2020, “Solid Particle Erosion Behaviour and Protective Coatings for Gas Turbine Compressor Blades-A Review”. Processes, 8(8), pp. 984. DOI: $10.3390 / \mathrm{pr} 8080984$

[20] Beardsley, M. Brad, 2008, "Potential use of quasicrystalline materials as thermal barrier coatings for diesel engine components". Retrospective Theses and Dissertations. 15661. DOI: $10.31274 /$ rtd180813-16873.

[21] Sánchez, A., Garcia de Blas, F.J., Algaba, J.M. et al., 1998, Application of Quasicrystalline Materials As Thermal Barriers in Aeronautics and Future Perspectives of Use For These Materials. MRS Online Proceedings Library, 553, pp. 447-458. DOI: 10.1557/PROC-553-447.

[22] Kaiser, A. Shklover, V., SteurerIvan, W. \& Vjunitsky, I., 2003, "Quasikristalline Legierungen und deren Verwendung als Beschichtung”. Pat. DE10358813A1.

[23] Clossen-von Lanken Schulz, Michael Kadau, Kai, 2012, “Turbine blade and method for producing a turbine blade with high surface hardness". Pat. DE102012219856A1.

[24] Milman, Yu.V., Efymov, N.A., Goncharova, IV, 2012, "Quasicrystals - a new class of solids with unique physical properties" (in Russian). Electron microscopy and strength of materials: Sat. scientific tr. Kyiv: IPM NAS of Ukraine, 18, pp. 3-15.

http://dspace.nbuv.gov.ua/handle/123456789/63528.

[25] Airbus reveals new zero-emission concept aircraft. https://www.airbus.com/newsroom/pressreleases/en/2020/09/airbus-reveals-new-zeroemission-concept-aircraft.html.

Accessed on 21-09-2020.

[26] "Fuel cell aircraft HY4 makes maiden flight". https://www.theengineer.co.uk/fuel-cell-aircraft-hy4makes-maiden-flight. The Engineer. 2016-09-30. Retrieved 2016-10-19.

[27] Dmytrenko, O.E., Dubinko, V.I., Borysenko, V. \& Irwin. K., 2020, “Synthesis of hydrogen storage materials in a $\mathrm{Ti}-\mathrm{Zr}-\mathrm{Ni}$ system using the hydride cycle technology during dehydrogenation by an electron beam in a vacuum". Problems of atomic science and technique (PAST), 1(125), pp. 198-205.

[28] Paserin, V., Marcuson, S., Shu, J. \& Wilkinson, D.S., 2003, “The Chemical Vapor Deposition Technique for Inco Nickel Foam Production-Manufacturing Benefits and Potential Applications". Cellular Metals and Metal Foaming Technology, Banhart, J., Fleck, N.A., Eds. MIT-Verlag: Berlin, Germany; pp. 31-38.

[29] Farafonov, D.P., Migunov, V.P., Saraev, A.A. \& Leschev, N.E., 2018, "Abradability and erosion resistance of seals in turbine engine air-gas channel" (in Russian). Proceedings of VIAM, 8(68). DOI: 10.18577/2307-6046-2018-0-8-70-80.

[30] Paun, F., Gasser, S. \& Leylekian, L., 2003, "Design of materials for noise reduction in aircraft engines". Aerospace Science and Technology, 7(1), pp. 63-72.

[31] Scarponi, C., 2016, "Carbon-carbon composites in aerospace engineering". Advanced Composite Materials for Aerospace Engineering. Processing, Properties and Applications, 2016, pp. 385-412. DOI: 10.1016/B978-0-08-100037-3.00013-4.

[32] Soutis, C., 2005, "Carbon fiber reinforced plastics in aircraft construction". Materials Science and Engineering: A, 412(1-2), pp. 171-176. DOI: 10.1016/j.msea.2005.08.064.

[33] Carbon Fiber in Aerospace Applications. https://www.pcmi-mfg.com/blog/carbon-fiber-inaerospace-applications. Accessed on 19-12-2020.

[34] Savage, G., 1993, Carbon-carbon Composites, Springer Science\&Business Media, DOI: 10.1007/978-94-011-1586-5.

[35] GE Redesigns Carbon Composite Blades for GE9X Engine. https://www.designnews.com/geredesigns-carbon-composite-blades-ge9x-engine. Accessed on 09-01-2021. 


\title{
PERSPEKTYWYWDROŻENIA NOWYCH MATERIAŁÓW I TECHNOLOGII W PRZEMYŚLE LOTNICZYM
}

\begin{abstract}
Abstrakt
W artykule rozważono główne materiały stosowane w budowie samolotów, zarówno w kadłubach jak w silnikach. Najpierw uwagę zwrócono na problemy, które skłaniają konstruktorów do wprowadzania nowych materiałów do produkcji samolotów.

Następnie przedstawiono charakterystykę wprowadzania żaroodpornych stopów tytanu, sposoby poprawy własności mechanicznych części wykonanych ze stopów tytanu oraz metody wytwarzania złożonych detali. Rozważono również inne materiały perspektywiczne dla przemysłu lotniczego, takie jak stopy o wysokiej entropii, kwazikryształy, materiały typu węgiel/węgiel oraz pianki niklowe.
\end{abstract}

Słowa kluczowe: silnik, stopy, przemysł lotniczy, proszek, materiał, metal 